SOSIOLIUM

\title{
IMPLEMENTASI KURIKULUM 2013 pada MATA PELAJARAN IPS KELAS VIII di SMP SEKECAMATAN GUNUNGPATI
}

\author{
Reza Nurmeipan, Fredy Hermanto ${ }^{\bowtie}$
}

Program Studi Pendidikan IPS, Fakultas Ilmu Sosial, Universitas Negeri Semarang, Indonesia

\section{Info Artikel}

Sejarah Artikel:

Disubmit: Mei 2020

Direvisi: Juni 2020

Diterima: Juli 2020

\section{Keywords:}

Implementation; Curriculum 2013; Social Sciences

\begin{abstract}
Abstrak
Guru memiliki peran mengimplementasikan kurikulum 2013 pada pelajaran IPS mengarahkan peserta didik untuk aktif saat pembelajaran. Penelitian ini bertujuan untuk mengetahui implementasi kurikulum 2013 pada mata pelajaran IPS kelas VIII di SMP Sekecamatan Gunungpati dilihat dari penyusunan perencanaan, pelaksanaan, pengembangan evaluasi, faktor pendukung serta faktor penghambat. Metode penelitian yang digunakan adalah metode kualitatif. Hasil penelitian menunjukkan bahwa (1) penyusunan perencanaan pembelajaran yang guru gunakan dalam bentuk silabus dan RPP mengacu pada standar proses. (2) proses pelaksanaan guru menggunakan metode diskusi kelompok dan pendekatan saintifik dengan model pembelajaran sesuai kurikulum 2013. (3) evaluasi pembelajaran guru merancang instrumen penilaian untuk menilai kemampuan peserta didik mencangkup ranah sikap, pengetahuan dan keterampilan. (4) faktor pendukung mengikutsertakan pelatihan MGMP membahas perangkatan pembelajaran, pelaksanaan dan teknik evaluaasi. Faktor penghambat guru masih sulit mengembangkan pembelajaran tipe HOTS pada ranah keterampilan.
\end{abstract}

\begin{abstract}
The teacher has a role in implementing the 2013 curriculum in social studies lessons in directing students to be active during learning. This study aims to determine the implementation of the 2013 curriculum in social science education class VIII in Junior High School, Gunungpati District, seen from the planning, implementation, evaluation development, supporting factors and inhibiting factors. The research method used is a qualitative method. The results showed that (1) the preparation of lesson plans that the teacher uses in the form of syllabus and lesson plans refers to the standard process. (2) The teacher implementation process uses the group discussion method and the scientific approach with a learning model according to the 2013 curriculum. (3) the evaluation of teacher learning designs an assessment instrument to assess the abilities of students in the realms of attitudes, knowledge and skills. (4) supporting factors include MGMP training which discusses learning tools, implementation and evaluation techniques. The inhibiting factor for teachers is still difficult to developtype learning HOTS in the realm of skills
\end{abstract}

(C) 2020 Universitas Negeri Semarang

\footnotetext{
Alamat korespondensi:

Gedung C1 Lantai 1 FIS Unnes

Kampus Sekaran, Gunungpati, Semarang, 50229

E-mail: fredy@mail.unnes.ac.id
}

E-ISSN 2685-4929 


\section{PENDAHULUAN}

Pendidikan merupakan unsur utama dalam pengembangan manusia Indonesia seutuhnya, oleh karena itu pengelolaan Pendidikan harus berorientasi kepada bagaimana menciptakan perubahan yang lebih baik. Undang-Undang nomer 20 tahun 2003 pasal 3 yaitu Pendidikan nasional merupakan berfungsi mengembangkan kemampuan dan membentuk watak serta dan peradaban bangsa yang bermartabat dalam rangka mencerdaskan kehidupan bangsa, bertujuan untuk berkembangnya potensi peserta didik agar menjadi manusia yang beriman dan bertakwa kepada Tuhan Yang Maha Esa, berakhlak mulia, sehat, berilmu, cakap, kreatif, mandiri, dan menjadi negara yang demokratis serta bertanggung jawab.

Kurikulum merupakan penjabaran tujuan pendidikan yang menjadi landasan program pembelajaran. Kurikulum yang dikembangkan di Indonesia adalah kurikulum 2013. Secara umum pelajaran IPS dalam kurikulum 2013 menerapkan pembelajaran diantaranya memberikan pengalaman langsung kepada peserta didik, sehingga apa yang dialami dan diperoleh peserta didik akan berdaya tahan lama untuk disimpan dalam memori peserta didik. Pembelajaran yang berbasis kontekstual dengan menerapkan pembelajaran tematik yang mempertimbangkan sebagian besar minat peserta didik yang mempermudahkan pelaksanaan pembelajaran dan pembelajaran berpusat pada peserta didik, diharapkan peserta didik mengalami proses pencarian pengetahuan dengan cara-cara terampil melalui mengamati, menanya, mengumpulkan infomasi /data, mencoba, menalar/mengasosiasi dan mengkomunikasikan pengetahuan yang diperolehnya dengan sikap yang baik.

Pusat kurikulum (2007: 14) menyatakan IPS adalah bahan kajian terpadu merupakan penyederhanaan, adaptasi, seleksi dan modifikasi yang diorganisasikan dari konsepkonsep dan keterampilan sejarah, geografi, sosiologi dan ekonomi. Jadi pelajaran IPS untuk tingkat sekolah sangat erat kaitanya dengan disiplin ilmu-ilmu sosial yang terintegrasi dengan humaniora dan ilmu pengetahuan alam yang dikemas secara ilmiah dan pedagogis untuk kepentingan pembelajaran di sekolah.

Pelajaran IPS menuntut pengajaran untuk terpadu dari berbagai disiplin ilmu sosial. Pratiknya dilapangan masih menunjukan bahwa sebagian besar guru mata pelajaran IPS mengalami kendala dalam melaksanakan program pembelajaran terpadu sebagai mana tuntutan kurikulum. Seperti hasil penelitian Wahidmurni (2014) menunjukan prioritas permasalahan yang dihadapi guru dalam melaksanakan pembelajaran mata pelajaran IPS secara terpadu adalah (1) kurangnya pemahaman tentang cara mengembangkan materi IPS secara terpadu, (2) kemampuan untuk merencanakan pembelajaran IPS terpadu, (3) kemampuan dalam melaksanakan penilaian pembelajaran, (4) media pembelajaran terbatas. Hal ini tentu saja dapat menghambat ketercapaian tujuan IPS itu sendiri yang dirumuskan atas dasar realitas dan fenomena sosial yang mewujudkan satu pendekatan interdisipliner dari aspek dan cabang-cabang ilmu sosial (sosiologi, sejarah, geografi, ekonomi).

Pembelakuan kurikulum 2013 pada mata pelajaran IPS secara keseluruhan sudah diterapkan di Indonesia, diantaranya pada kecamatan Gunungpati di beberapa Sekolah Menengah Pertama yaitu SMP Negeri 22 Semarang sudah menerapkan kurikulum 2013 sejak tahun 2014. Penerapan kurikulum 2013 pada awalnya diterapkan hanya pada kelas 7 dan 8 untuk kelas 9 sendiri memang masih tetap menggunakan Kurikulum Tingkat Satuan Pendidikan (KTSP) karena penerapan kurikulum 2013 di SMP Negeri 22 Semarang secara bertahap. Sedangkan di SMP Negeri 41 dan SMP Semesta Bilingual Boarding School Semarang, penerapan kurikulum 2013 diberlakukan sejak tahun 2016 karena pada awal tahun ajaran 2014/2015 penerapan kurikulum 2013 belum semua guru siap menerapkan kurikulum 2013 apalagi rancangan perangkat pada kurikulum 2013 cukup kompleks sehingga guru memerlukan waktu yang tidak sedikit untuk memahami rancangan tersebut. Ketersediaan sarana dan prasarana dalam mendukung pembejaran kurikulum 2013 masih terbatas. Berdasarkan latar belakang tersebut 
maka peneliti tertarik untuk mengkaji "Implementasi Kurikulum 2013 pada Mata Pelajaran IPS Kelas VIII di SMP Sekecamatan Gunungpati".

Rumusan masalah dalam penelitian ini adalah 1) Bagaimanakah proses penyusunan perencanaan perangkat pembelajaran mata pelajaran IPS kelas VIII di SMP Sekecamatan Gunungpati 2) Bagaimanakah pelaksanaan implementasi kurikulum 2013 pada mata pelajaran IPS kelas VII di SMP Sekecamatan Gunungpati 3) Bagaimanakah pengembangan evaluasi mata pelajaran IPS kelas VIII di SMP Sekecamatan Gunungpati 4) apa saja faktor pendukung dan penghambat implementasi kurikulum 2013 pada mata pelajaran IPS kelas VIII di SMP sekecamatan Gunungpati.

Penelitian ini bertujuan untuk : (1) mengemukakan proses penyusunan perangkat pembelajaran mata pelajaran IPS kelas VIII di SMP Sekecamatan Gunungpati, membuktikan pelaksanaan implementasi kurikulum 2013 pada mata pelajaran IPS kelas VII di SMP sekecamatan Gunungpati, (3) menelaah pengembangan evaluasi implementasi kurikulum 2013 pada mata pelajaran IPS kelas VIII di SMP sekecamatan Gunungpati, (4) mengemukakan faktor pendukung dan penghambat implementasi 2013 pada mata pelajaran IPS kelas VIII di SMP sekecamatan Gunungpati.

Hasil penelitian ini dapat menambah wawasan bagi peneliti, bagi guru meningkatkan profesionalitas diri sehingga mampu mengembangkan dan melaksanakan kurikulum 2013 khususnya guru mata pelajaran IPS.

\section{METODE}

Penelitian ini menggunakan penelitian Kualitatif Deskriptif. Penelitian kualitatif adalah penelitian yang mendeskripsikan atau menggambarkan objek yang diteliti, dimana kondisi objek tersebut alamiah, peneliti sebagai instrumen kunci, tenik pengumpulan data dilakukan secara triangulasi (gabungan), analisis data bersifat induktif, serta hasil penelitian lebih menekankan makna dari pada generalisai (Sugiyono, 2016: 9).
Peneliti menggunakan pendekatan kualitatif agar dapat memahami permasalahan yang dikaji dan mendapatkan data terkait aktivitas guru IPS dalam Impelementasi Kurikulum 2013 pada mata pelajaran IPS di kecamatan Gunungpati yang terdapat beberapa sekolah pada jenjang tingkat dasar (SMP) negeri maupun swasta yang memiliki input berbedabeda serta sarana prasarana yang berbeda-beda pula. Pada penelitian ini lokasi yang dipilih ada tiga SMP yaitu SMP Negeri 22 Semarang, SMP Negeri 41 Semarang dan SMP Semesta Bilingual Boarding School Semarang. Fokus penelitian ini adalah impelementasi kurikulum 2013 pada mata pelajaran IPS seperti penyusunan perangkat pembelajaran IPS, pelaksnaan pembelajaran, faktor pendukung dan penghambat pembelajaran IPS serta pengembangan evaluasi pembelajaran IPS di SMP SeKecamatan Gunungpati.

Teknik pengumpulan data dilakukan dengan teknik observasi, wawancara, dokumentasi dan catatan lapangan. observasi dilakukan peneliti melakukan pengamatan langsung dalam kegiatan pembelajaran di kelas. Wawancara dilakukan untuk mendapat informasi dari Guru, Kepala Sekolah dan siswa disinkronkan dengan hasil observasi. Dokumentasi mengambil data baik gambar maupun dokumen-dokumen atau arsip-arsip. Sedangkan catatan lapangan digunakan oleh peneliti untuk mencatat secara detail informasi yang ditemui saat berada di lapangan.

\section{HASIL DAN PEMBAHASAN}

\section{Penyusunan Perencanaan Perangkat \\ Pembelajaran Mata Pelajaran IPS Kelas VIII di SMP Sekecamatan Gunungpati}

Permendikbud no. 22 tahun 2016 tentang standar proses pendidikan dasar dan menengah menjelaskan Perencanaan pembelajaran dirancang dalam bentuk Silabus dan Rencana Pelaksanaan Pembelajaran (RPP) yang mengacu pada Standar Isi. Perencanaan pembelajaran meliputi penyusunan rencana pelaksanaan pembelajaran dan penyiapan media dan sumber belajar, perangkat penilaian pembelajaran, dan skenario pembelajaran. 
Berdasarkan hasil penelitian diketahui bahwa guru IPS pada tiga SMP di Kecamatan Gunungpati menggunakan silabus sebagai acuan untuk membuat RPP yang terdiri dari beberapa komponen : 1) Kompetensi Dasar 2) Indikator Pencapaian Kompetensi dan Tujuan Pembelajaran, perumusan Indikator Pencapaian Kompetensi (IPK) pada mata pelajaran IPS dirancang guru dengan menggunakan Kata Kerja Operasional (KKO) atau Taksonomi Bloom yang didapat ukur dari C1 sampai C6 yang mencangkup ranah pengetahuan, sikap, dan keterampilan untuk memberikan kegiatan pembelajaran yang efektif kepada peserta didik 3) Kegiatan Pembelajaran, proses pembelajaran mata pelajaran IPS pada kurikulum 2013 dikembangkan mengajak peserta didik untuk aktif. Penggunaan metode diskusi dan model problem based learning, discovery diterapkan kepada peserta didik untuk mengungkapkan permasalahan materi yang diberikan guru dengan mengaitkan dengan kondisi yang sedang beredar di lingkungan masyarakat melalui kegiatan mengamati, menanya, menganalisis, dan menyajikan misalnya keterampilan dalam bermasyarakat dari mempelajari sosiologi, keterampilan terkait dunia usaha dari materi ekonomi, keterampilan dalam pelestarian lingkungan dari materi geografi 4) Media dan Sumber Belajar, Guru IPS pada tiga SMP di Kecamatan Gunungpati menentukan media dan sumber belajar mata pelajaran IPS perlu merujuk pada KD supaya materi yang disampaikan ke peserta didik dapat relevan. Sumber belajar disesuaikan dengan karakteristik peserta didik artinya isi sumber belajar mudah dipahami oleh peserta didik, sumber belajar juga harus terjangkau oleh peserta didik misalnya pembelajaran IPS bisa menggunakan lingkungan sekitarnya atau buku paket IPS yang sudah disediakan sekolah dari pemerintah seperti buku IPS kelas VIII dari Kemendikbud, buku referensi pendamping siswa sedangkan untuk media menggunakan LCD proyektor gambar video dan media yang berhubungan dengan materi IPS. 5) Alokasi Waktu, hasil penelitian guru IPS pada tiga SMP di Kecamatan Gunungpati diketahui alokasi waktu perlu mempertimbangkan diantaranya memperhatikan kesukaran materi, kedalaman materi, tingkat pentingnya materi yang dipelajari artinya alokasi waktu mengacu pada KD sehingga mengetahui kapasitas materi yang akan diajarkan kepada peserta didik 6) Penilaian, sistem penilaian guru IPS pada tiga SMP di Kecamatan Gunungpati untuk kurikulum 2013 yaitu aspek pengetahuan membuat soal pilihan ganda, jawaban singkat atau tugas sedangkan aspek sikap dan ketermpilan membuat jurnal atau pengamatan langsung kepada perserta didik.

Pelaksanaan Implementasi Kurikulum 2013 pada Mata Pelajaran IPS Kelas VIII di SMP Sekecamatan Gunungpati

Permendikbud no. 22 tahun 2016 tentang standar proses pendidikan dasar dan menengah menjelaskan pelaksanaan pembelajaran merupakan implementasi dari RPP, meliputi kegiatan pendahuluan, inti dan penutup.

\section{Kegiatan Pendahuluan}

Berdasarkan hasil pengamatan diketahui bahwa guru IPS pada tiga SMP di Kecamatan Gunungpati untuk kegiatan pendahuluan guru menyiapkan peserta didik secara fisik maupun psikis. Secara fisik diawali dengan berdoa bersama, mengecek kehadiran siswa dan mengecek kodisi kelas menciptakan suana pembelajaran yang nyaman. Secara psikis guru memberikan apersepsi dengan tanya-jawab guna mengaitkan materi yang sebelumnya dipelajari dengan materi yang akan dipelajari, dilanjutkan memotivasi peserta didik seperti pada materi materi mobilitas sosial vertikal naik guru mengaitkan dengan profesi-profesi yang ada dilingkungan peserta didik agar termotivasi menjadi orang yang sukses.

\section{Kegiatan Inti}

Proses pelaksanaan kegiatan inti mata pelajaran IPS pada tiga SMP di kecamatan Gunungpati menunjukan kegiatan belajar mengajar yang menggunakan metode dikusi dan model pembelajaran discovery dan problem based learning sesuai pembelajaran kurikulum 2013 membantu peserta didik untuk mengembangkan baik dari aspek sikap, aspek pengetahuan dan aspek keterampilan. Aspek sikap Berhubungan dengan karakter peserta didik yang diamati guru 
selama mengikuti pembelajaran, oleh karena itu diskusi kelompok juga memiliki unsur-unsur dalam penilaian seorang guru yang sesuai tuntutan pembelajaran kurikulum 2013. Aspek pengetahuan, pada materi mobilitas sosial peserta didik diajak untuk mengamati, mengumpulkan infomasi dengan gambar, video dan fenomena sosial dimasyarakat untuk memudahkan peserta didik dalam memahami teori dengan adanya contoh nyata di kehidupan sehari-hari. Aspek keterampilan mencakup aspek menanya dan menyaji menjadikan peserta didik terampil bertanya dan melatih mengemukakan pendapat didepan umum melalui presentasi.

\section{Kegiatan Penutup}

Proses kegiatan penutup yang dilakukan guru IPS pada tiga SMP di Kecamatan Gunungpati yaitu guru memberikan memberikan kesimpulan dan penguatan konsep kepada peserta didik terhadap materi yang telah dipelajari. Pemberian soal sebagai tindak lanjut dengan memberikan test lisan maupun tertulis untuk mengetahui pencapaian tujuan pembelajaran dan pemahaman peserta didik tehadap materi yang disampaikan. Umpan balik diberikan untuk mengetahui keberhasilan guru menerangan materi IPS kepada peserta didik yang telah disampaikan.

\section{Pengembangan Evaluasi Mata Pelajaran IPS Kelas VIII di SMP Sekecamatan Gunungpati}

Permendikbud nomor 23 tahun 2016 tentang standar penilaian pendidikan bab II pasal 3 lingkup penilaian menjelaskan penilaian hasil belajar peserta didik pada pendidikan dasar dan pendidikan menengah meliputi aspek sikap, pengetahuan, dan keterampilan.

\section{Penilaian Sikap}

Berdasarkan hasil penelitian yang dilakukan menunjukan bahwa guru IPS pada tiga SMP di Kecamatan Gunungpati penilaian aspek sikap meliputi jurnal, penilaian antar teman, dan penilaian diri. Penggunaan Jurnal dilakukan untuk mencatat perilaku peserta didik yang menonjol baik sikap religious, bertangggung jawab atas tugas yang diberikan guru, perilaku santun atau tidak selama mengikuti pelajaran IPS. penilaian antar teman guru bertanya kepada teman sebaya peserta didik guna mengetahui mendetail informasi tentang perilaku peserta didik. Penilaian diri, penilaian ini dengan cara membagikan angket kepada masing-masing peserta didik untuk mengetahui kejujuran peserta didik itu sendiri. Penilaian aspek sikap dikoordinasikan dengan orang tua peserta didik melalui grup Whatsup.

\section{Penilaian Pengetahuan}

Penilaian pengetahuan pada tiga SMP di Gunungpati adalah menggunakan test tertulis, penggunaan test tertulis sendiri dapat berupa post tes sebelum pembelajaran dimulai, kuis setelah materi selesai disampaikan guru. Pembuatan tes tertulis guru tetap menyesuaikan indikator, test tertulis berupa pilihan ganda maupun essay yang meliputi latihan soal, ulangan harian, ulangan tengah semester, ulangan akhir semester dan penilaian kenaikan kelas. Hasil penilaian pengetahuan ini untuk mengetahui apakah peserta didik telah mencapai KKM atau tidak yang nantinya akan dilanjutkan remidial.

\section{Penilaian Keterampilan}

Penilaian keterampilan dapat dinilai guru melalui obeservasi secara langsung maupun dengan menggunakan jurnal catatan atau rubik berdasarkan kisi-kisi penilaian keterampilan. Pada pembelajaran IPS peserta didik diperintahkan membuat peta serta globe dengan langkah-langkahnya, pembuatan video yang bertema materi IPS, madding, dan prensentasi melatih public speaking, mengembangkan cara berpendapat peserta didik pada materi yang diajarkan.

\section{Faktor Pendukung dan Penghambat Implementasi Kurikulum 2013 pada Mata Pelajaran IPS Kelas VIII di SMP Sekecamatan Gunungpati \\ Sanjaya (2016: 52) teacher properties,} berhubungan sifat yang memiliki guru, misalnya sikap guru terhadap professional, sikap guru terhadap siswa, kemampuan atau inteligensi guru, motivasi dan kemampuan mereka baik kemampuan dalam perencanaan dan evaluasi 
pembelajaran maupun kemampuan dalam penguasaan materi pelajaran.

\section{Faktor Pendukung}

Faktor pendukung penyusunan perencanaan pembelajaran IPS kurikulum 2013 bahwa sekolah mengikutisertakan MGMP baik tingkat kota maupun tinggkat sekolah, pelatihan, seminar dan workshop dari dinas pendidikan maupun dari universitas keguruan didalamya membahas tentang sosialisasi dan penerapan kurikulum terbaru yaitu kurikulum 2013 terkait silabus dan RPP seperti pemetaan materi pembelajaran IPS, media yang akan digunakan dan sumber-sumber pembelajaran yang relevan dan teknik evaluasi pembuatan soal harus mengarah tipe HOTS.

Fasilitas sekolah menjadi pendukung pelaksanaan pembelajaran adanya LCD proyektor membantu guru dalam menyampaikan materi dengan menayangkan video dan gambar serta lingkungan sekolah yang strategis dekat dengan Museum Ronggo Warsito, Kampung Wisata Kandri, Lawang Sewu dan Kota Lama bisa belajar secara kontekstual pada materi IPS.

\section{Faktor Penghambat}

Faktor penghambat dioleh guru maupun peserta didik. Faktor guru ketidak mampuan menentukan alokasi dengan adanya materi IPS yang memuat banyak materi sementara alokasi waktu yang diberikan terbatas dan membuat soal tipe HOTS yang dikembangkan kata operasional dari C4 sampai C6 bahwa untuk C6 mengarah kepembuatan produk yang memerlukan waktu relatif lama. Faktor peserta didik disebabkan oleh kecerdasan emsional peserta didik tidak siap menerima pembelajaran IPS sehingga saat guru menjelaskan materi IPS peserta didik kurang memperhatikan.

\section{SIMPULAN}

\section{Kesimpulan}

Berdasarkan hasil penelitian yang telah dipaparkan, maka kesimpulan yang dapat diambil ialah sebagai berikut:

1. Proses penyusunan perencanaan pembelajaran yang di gunakan guru IPS pada tiga SMP di Kecamatan Gunungpati dirancang dalam bentuk silabus dan RPP yang mengacu pada standar proses. Penyusunan silabus dan RPP disesuaikan dengan Kompetensi Dasar yang diturunkan menjadi IPK yaitu sasaran pembelajaran yang akan dicapai oleh peserta didik.

2. Pelaksanaan implementasi kurikulum 2013 pada mata pelajaran IPS kelas VIII di SMP sekecamatan Gunungpati terbagi menjadi tiga bagian, yaitu Kegiatan pendahuluan menunjukan guru menyiapkan peserta didik secara fisik maupun psikis. Kegiatan inti guru menggunakan metode diskusi kelompok dan pendekatan saintifik dengan model pembelajaran sesuai kurikulum 2013. Kegiatan penutup guru memberikan kesimpulan dan penguatan konsep materi kepada peserta didik.

3. Pada evaluasi pembelajaran guru merancang instrumen penilaian untuk menilai kemampuan peserta didik mencangkup ranah sikap, pengetahuan dan keterampilan.

4. Faktor pendukung mengikutsertakan pelatihan guru melalui MGMP yang membahas penyusunan perangkat perencanaan pembelajaran serta pelaksanaannya dan teknik evaluasi, faktor penghambat guru masih sulit mengembangkan pembelajaran tipe HOTS pada ranah keterampilan melihat waktu pembelajaran IPS terbatas.

\section{Saran}

Berdasarkan hasil penelitian, maka dapat disampaikan saran sebagai berikut :

1. Bagi sekolah, Penerapan kurikulum 2013 dibutuhkan kerjasama antara Dinas Pendidikan kota Semarang dan Kepala Sekolah untuk meningkatkan kemampuan guru pada tiga SMP di Kecamatan Gunungpati dalam mendidik melalui pelatihan agar pengetahuan dan kemampuan untuk mengembangkan pembelajaran IPS di kurikulum 2013 yang mencangkup ranah sikap, ranah pengetahuan dan ranah keterampilan terus bertambah. 
2. Bagi guru, tingkatkan selalu untuk memperhatikan perkembangan peserta didik, agar dalam pembelajaran sesuai dengan kapasitas dan kemampuan berpikir terutama pada mata pelajaran IPS.

3. Bagi peneliti, Keterbatasan yang dimiliki dalam penelitian ini yaitu berupa cakupan sekolah yang hanya pada tiga SMP dari enambelas SMP di Kecamatan Gunungpati, oleh karena itu disarankan pada peneliti selanjutnya yang akan melakukan penelitian sejenis untuk memperbanyak cakupan SMP sehingga didapatkan hasil yang lebih valid dan lebih mendalam.

\section{DAFTAR PUSTAKA}

Peraturan Menteri Pendidikan dan Kebudayaan Republik Indonesia Nomor 22 Tahun 2016 tentang Standar Proses Pendidikan Dasar dan Menengah. 2016. Jakarta. plh. Kepala Biro Hukum dan Oraganisasi Kepala Biro Kepagawaian.

Peraturan Menteri Pendidikan dan Kebudayaan Republik Indonesia Nomor 23 Tahun 2016 tentang Standar Penilaian Pendidikan. 2016. Jakarta. plh. Kepala Biro Hukum dan Oraganisasi Kepala Biro Kepagawaian.

Sanjaya dan Budimanjaya. 2017. Paradigma Baru Mengajar. Jakarta: Prenadamedia Group.

Sanjaya, Wina. 2016. Strategi Pembelajaran Berorientasi Standar Proses Pendidikan. Jakarta: Prenadamedia Group.

Sugiyono. 2016. Metode Penelitian Pendidikan. Bandung: Alfabeta.

Wahidmurni. 2017. Metodologi Pembelajaran IPS. Yogyakarta: Ar- Ruzz Media. 